\title{
The Liagoraceae (Rhodophyta: Nemaliales) of the Hawaiian Islands. 1: First Record of the Genus Gloiotrichus for Hawai'i and the Pacific Ocean ${ }^{1}$
}

\author{
fobn M. Huisman and Isabella A. Abbott ${ }^{2}$
}

\begin{abstract}
Gloiotricbus fractalis Huisman \& Kraft is documented for the first time from the island of Hawai' $i$, Hawaiian Islands, which also represents the first record for the Pacific Ocean. The single specimen on which the record is based is $12 \mathrm{~cm}$ in height, extremely mucilaginous, with percurrent primary axes and irregularly arranged lateral branches. Carpogonial branches are borne on the basal one to three cells of cortical fascicles; when mature they are five to eight cells long and straight. Before fertilization, cells of the carpogonial branch produce several lateral branches similar in morphology to cortical filaments. After presumed fertilization the zygote (= postfertilization carpogonium) divides transversely and gonimoblast initials are produced from both of the resultant cells. Mature carposporophytes are spherical, with terminal carposporangia and a fusion cell formed from the cells of the carpogonial branch and basal cells of lateral filaments. The Hawaiian specimen is identical in virtually all respects to those from the Indian Ocean type locality in the Houtman Abrolhos Islands of Western Australia.
\end{abstract}

The Monotypic genus Gloiotrichus was erected by Huisman and Kraft (1994) for plants collected from the central west coast of Australia. Distinguishing features include an extremely mucilaginous habit, elongate carpogonial branches bearing secondary lateral branches, production of the gonimoblast from both cells of the transversely divided zygote, and formation of a postfertilization fusion cell comprising cells of the carpogonial branch. Thus far the genus is known only from the Pelsaert and Easter groups of the Houtman Abrolhos, a cluster of mainly coral offshore islands situated at a latitude of 28$29^{\circ} \mathrm{S}$ (see Huisman 1997).

Recently a specimen referable to Gloiotricbus and seemingly identical to $G$. fractalis

\footnotetext{
${ }^{1}$ Research supported by the David and Lucile Packard Foundation. Manuscript accepted 25 October 2002.

2 Department of Botany, University of Hawaili at. Mānoa, 3190 Maile Way, Honolulu, Hawai'i 96822.
}

Pacific Science (2003), vol. 57, no. 3:267-273

(C) 2003 by University of Hawai'i Press

All rights reserved was collected from the island of Hawai $i$ in the Hawaiian Islands. This represents the first record of the genus outside the immediate vicinity of its Indian Ocean type locality. A description of the Hawaiian specimen and a comparison between it and the Australian specimens are presented here.

This contribution is the first in a proposed series describing various members of the Liagoraceae of Hawai'i. All will follow a similar format, and some will include emended generic and species descriptions.

\section{MATERIALS AND METHODS}

The specimen was collected while scuba diving. Portions of the plant for microscopical examination were decalcified in $1 \mathrm{~N} \mathrm{HCl}$, stained in $1 \%$ aniline blue, then mounted in a $50 \%$ corn syrup (Karo, CPC International) solution and lightly squashed to separate the filaments. Herbarium specimens and slide preparations are held in BISH. Herbarium abbreviations follow Holmgren et al. (1990). Slide preparations were examined with a microscope (Olympus BX3) and photographed using a digital camera (Olympus D11). 


\section{RESULTS}

Genus Gloiotrichus Huisman \& Kraft

Eur. 7. Pbycol. $29: 74$ (1994).

Type: G. fractalis Huisman \& Kraft

GENERIC DESCRIPTION: Thalli (gametophytes) upright, epilithic, soft, and lubricous, with a discoid holdfast and percurrent axes with regularly or irregularly produced lateral branches. Axes terete, multiaxial, of uniform diameter with attenuate apices, and lightly calcified around the medulla. Medulla composed of longitudinal filaments and cortex of subdichotomously divided anticlinal filaments with occasional rhizoidal filaments issuing from basal cells. Distal cells of cortical fascicles ellipsoid to spherical, proximal cells elongate. Plants monoecious. Spermatangial branches arise on subterminal cortical cells, become much branched, and when mature bear terminal spermatangia. Carpogonial branches arise on basal 1-3 cells of cortical fascicles, are 5-8 cells long, straight, and bear secondary lateral filaments of similar appearance to normal cortical filaments on midbranch cells. Postfertilization carpogonium (= zygote) divides transversely, with both derivatives producing the gonimoblast. Carposporophytes compact, with apical carposporangia and a fusion cell formed from cells of carpogonial branch and basal cells of secondary lateral filaments. Tetrasporophytes unknown.

Gloiotrichus fractalis Huisman \& Kraft Eur. 7. Pbycol. $29: 74$ (1994).

Specimen examined: 'Au'au Pt., Hawai'i, epilithic at $15 \mathrm{~m}$ depth, 5 April 2002, M. Hughes, км 5414 (Figure 1).

HABIT AND VEGETATIVE STRUCTURE: The thallus is $12 \mathrm{~cm}$ high, extremely lubricous, and has several percurrent axes that are irregularly laterally branched (Figure 1). All axes are terete, lightly calcified around the medulla, and with calcification suspended in the mucilage (Figure 2), with the main axes 1-2 $\mathrm{mm}$ diam. and lateral branches to $1 \mathrm{~mm}$ diam. The medulla is composed of longitudi- nally aligned filaments (Figure 3) plus adventitious filaments that arise from the basal cells of cortical fascicles. Cells of the medullary filaments are elongate, $10-12 \mu \mathrm{m}$ diam. near the apex, and up to $170 \mu \mathrm{m}$ diam. in older portions. Cortical fascicles are 200-300 $\mu \mathrm{m}$ long and are borne on subisodiametric basal cells; they are subdichotomously branched, with the distal two to four cells unbranched (Figure 4). Lower cells of cortical fascicles are elongate, with progressively more distal cells becoming ellipsoid or subspherical (to $25 \mu \mathrm{m}$ diam.), the penultimate cell generally the broadest of the filament, and the apical cell subspherical (Figure 4). Small cells with darkly staining contents (Figure 4) or hairs are borne singly or in pairs on the apical cells of cortical filaments. These appear to be regularly shed because remnant walls are generally visible (Figures 4, 5). Cortical filaments that arise from adventitious filaments are often unbranched and more slender than typical filaments. Most cells have a deeply lobed plastid and a conspicuous central pyrenoid (Figure 5).

REPRODUCTION: The specimen is monoecious, with ovoid spermatangia 3-5 $\mu \mathrm{m}$ in length formed on much-divided branches arising from the outer cells of cortical filaments (Figure 6). Carpogonial branches (Figure 7) are straight, five- to eight-celled, and arise from the basal or suprabasal cells of cortical fascicles, or directly from rhizoidal filaments (Figure 8), with most cells proximal to the carpogonium and hypogynous cells ultimately bearing lateral filaments resembling vegetative filaments (Figure 9). Initiation of the lateral filaments begins in the proximal portion of the branch and progresses distally. Generally the cell below the carpogonium (= hypogynous cell) is slightly broader than lower cells and remains naked (Figure 9). The lower cells of the carpogonial branch often bear secondary carpogonial branches, particularly when the primary carpogonial branch has not been fertilized. After presumed fertilization the zygote divides transversely. The origin of the gonimoblast was not clearly seen because no immediate postfertilization stages were present in the material and once postfertilization fusion of the carpogonial branch 

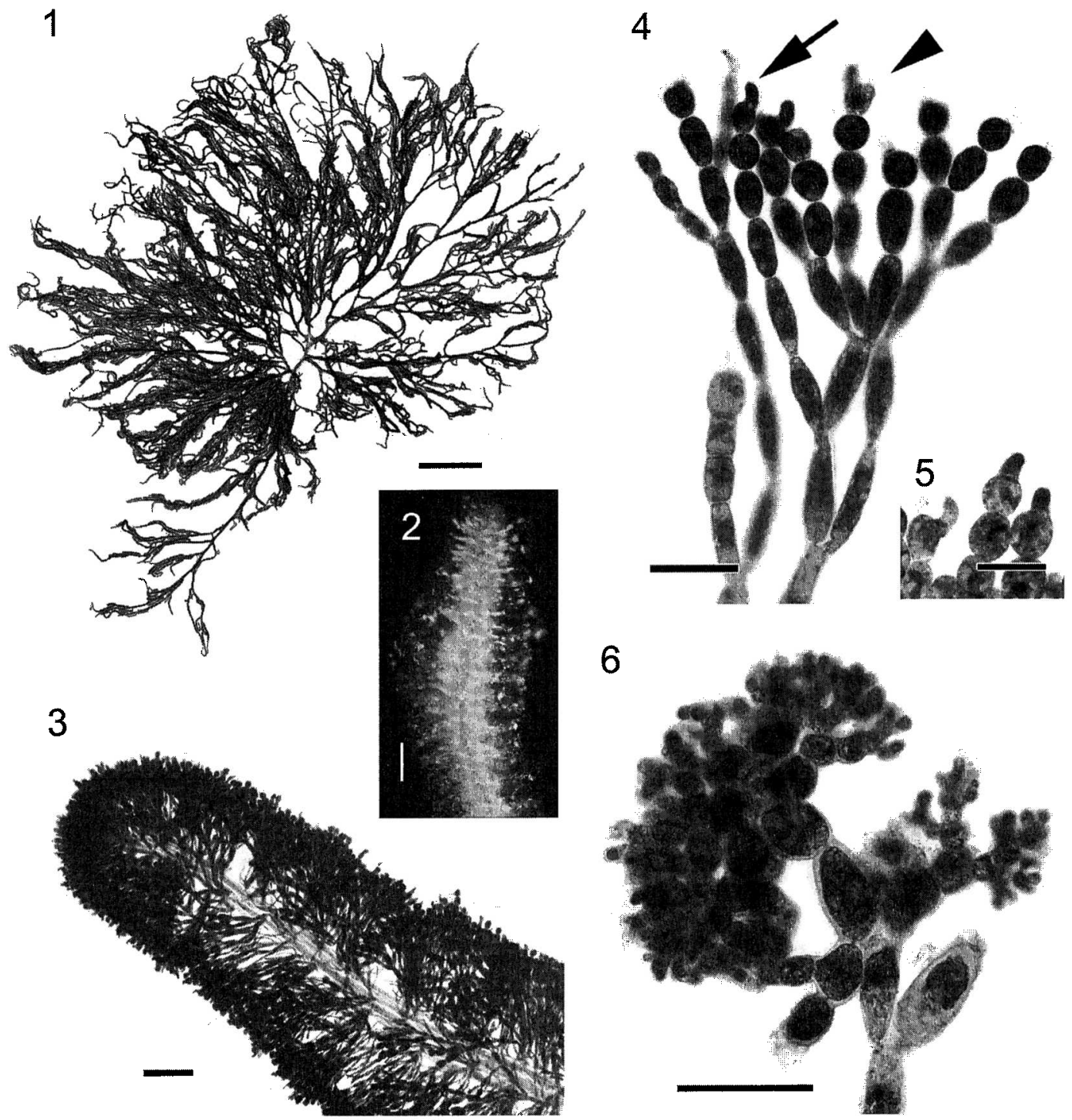

FigURES 1-6. Gloiotrichus fractalis Huisman \& Kraft. All км 5414. 1. Herbarium preparation of specimen from Hawai' i. Scale $=2 \mathrm{~cm}$. 2. Apex of branch showing calcification around the medulla and lying loose in the mucilage. Scale $=500 \mu \mathrm{m}$. 3. Apex of decalcified branch showing multiaxial construction and anticlinal cortical fascicles. Scale $=100 \mu \mathrm{m} .4$. Detail of cortical filaments. A slightly offset small cell can be seen at the apex of one filament (arrow) and empty walls where these cells have been shed (arrowhead). Scale $=40 \mu \mathrm{m}$. 5. Detail of small cells at apices of cortical filaments. Scale $=20 \mu \mathrm{m}$. 6. Spermatangial clusters formed at the apices of cortical filaments. Scale $=40 \mu \mathrm{m}$.

cells commences it is difficult to follow the process. Based on the morphology of the prefertilization carpogonial branch, in which the hypogynous cell is generally naked and slightly broader than lower cells (see arrow in
Figure 9), and assuming the cells indicated in Figures 10 and 11 are also the hypogynous cells, it appears that the gonimoblast arises from both cells of the divided zygote (i.e., all cells distal to the hypogynous cell). A fusion 


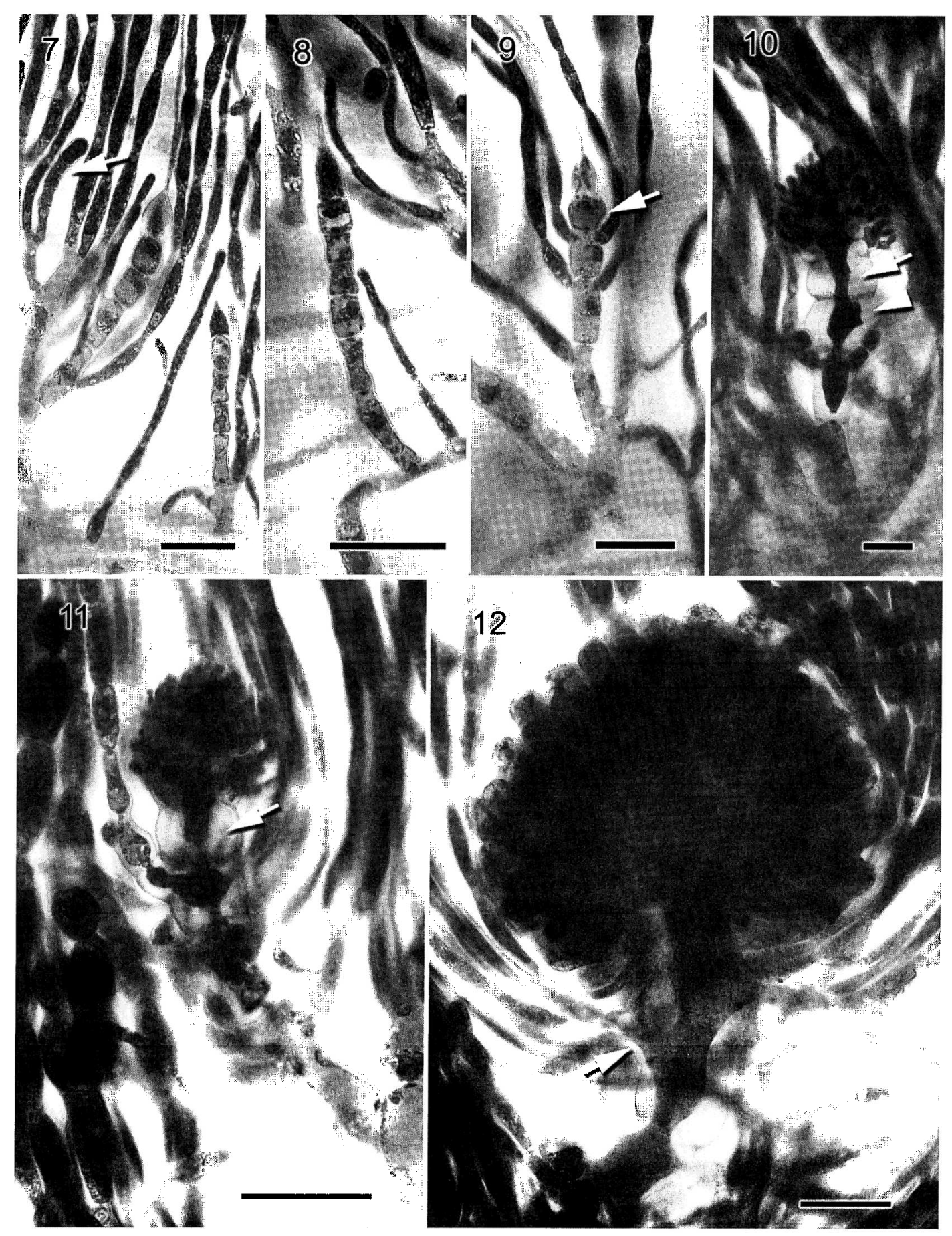


cell (Figures 10-12) is formed from cells of the carpogonial branch and lower cells of the lateral branches, with the distal portion of the lateral branches often being shed. Mature carposporophytes (Figure 12) are $185-250 \mu \mathrm{m}$ diam., with terminal, clavate to obovoid carposporangia measuring $30-40$ by $15-20 \mu \mathrm{m}$.

\section{DISCUSSION}

The Hawaiian specimen of Gloiotrichus fractalis displays all of the features considered characteristic for the genus, including the production of an elongate carpogonial branch that bears lateral branches of normal cortical appearance and the formation of a fusion cell comprising the cells of the carpogonial branch (Huisman and Kraft 1994, Huisman 2000). Unfortunately the immediate postfertilization development could not be observed clearly in our material, which had abundant carpogonial branches but very few carposporophytes, so the production of the gonimoblast from both cells of the transversely divided zygote could not be ascertained with absolute certainty. Because Huisman and Kraft (1994) regarded this feature to be of generic significance, an explanation of the stages observed in the Hawaiian specimen is warranted. The development of the carpogonial branch includes the production of lateral branches from cells proximal to the hypogynous cell (= the cell below the carpogonium), as can be seen in Figure 9 (the arrow indicates the hypogynous cell). If the stages of postfertilization development follow those described by Huisman and Kraft (1994), the zygote would subsequently divide transversely and the gonimoblast arise from both of the cells produced. Thus later stages would show a naked cell (the hypogynous cell) subtending the gonimoblast. If we follow the progress of the hypogynous cell in our material, it appears to subtend the gonimoblast (Figure 11, arrow indicates hypogynous cell), which therefore has arisen from both cells of the divided zygote and the process agrees with that described by Huisman and Kraft (1994). Some potentially confusing stages are present, however. The young carposporophyte depicted in Figure 10 shows a carpogonial branch with two naked cells below the gonimoblast, which, if the proximal of the two naked cells (arrowhead) is interpreted as the hypogynous cell, would suggest that the gonimoblast is arising from only the distal cell of the divided zygote (i.e., the cell indicated is the proximal cell of the divided zygote). What appears to be shown in Figure 10, however, is that the laterals on the subhypogynous cell have been shed (their original point of attachment is indicated by a couple of protrusions). Thus the cell indicated in Figure 10 is the hypogynous cell and the gonimoblast is arising from all cells distal to it. All of the postfertilization stages seen in our material, therefore, can be interpreted as agreeing with the description of Huisman and Kraft (1994).

As indicated by Huisman and Kraft (1994), Gloiotrichus shows similarities to Trichogloea Kützing, but differs in the morphology of the lateral branches on the carpogonial branch, with those of Trichogloea being highly modified (Huisman and Kraft 1994: fig. 11, Abbott 1999: figs. 18C,E, Huisman 2000:35), whereas those of Gloiotrichus are similar to vegetative filaments (Huisman and Kraft 1994: figs. 7-9, Huisman 2000:31), and also in the production of the gonimoblast in Trichogloea from both cells (as opposed to only the upper cell in Gloiotrichus) of the divided carpogonium. Moreover the architecture of the spermatangial branches further distinguishes Gloio-

Figures 7-12. Gloiotricbus fractalis Huisman \& Kraft. All км 5414. 7. Developing carpogonial branches. Arrow indicates an immature branch. Scale $=40 \mu \mathrm{m}$. 8. Carpogonial branch arising from a rhizoidal filament. Scale $=40 \mu \mathrm{m}$. 9. Mature carpogonial branch with lateral filaments. Arrow indicates the hypogynous cell. Scale $=40$ $\mu \mathrm{m}$. 10. Young gonimoblast at an early stage of fusion-cell formation. Arrow indicates the hypogynous cell. Lateral branches on the subhypogynous cell (arrowhead) apparently have been shed. Scale $=20 \mu \mathrm{m}$. 11. Young gonimoblast at a stage comparable with that shown in Figure 9. Arrow indicates the hypogynous cell. The lateral branches on the subhypogynous cell are still present. Scale $=40 \mu \mathrm{m}$. 12. Mature carposporophyte with fusion cell (arrow) formed from the cells of the carpogonial branch. Scale $=40 \mu \mathrm{m}$. 
tricbus from Trichogloea, with those of the latter produced in whorls on intercalary cortical cells.

Huisman and Kraft (1994) designated the small cells that are formed distally on the outer cortical cells (see Figure 5 and cells indicated in Figure 4) as "glandular" cells due to their appearance resembling that of "gland" cells (also known as vesicular cells) in other red algae. However, because no glandular function has been demonstrated for these cells it is perhaps best not to confer them with any particular role. As can be seen in Figure 4 (arrowhead), the contents of these cells are often shed, leaving behind a remnant wall. This type of behavior is most often seen in reproductive cells such as monosporangia. Although we cannot speculate as to the role of these cells, a couple of observations are pertinent. First, their contents are homogeneous in appearance, with perhaps only a few small vacuoles, and stain darkly (compare the distal cells shown in Figure 5 with those subtending them). This type of appearance is suggestive of what are known as "gland" cells in other red algae (e.g., Coelartbrum [see Huisman 1996]), but (in Gloiotrichus at least) it is also found in actively growing cells such as the apical cells of developing carpogonial branches. Second, in identical positions on the Australian specimens of Gloiotrichus (but not well developed in the Hawaiian plant) are occasional hairs. These are elongate, with distally inflated tips containing cytoplasm identical in appearance to that of the small cells. At the base of the hairs are often remnant wall collars, indicating that the hairs either arise within the remnant walls of the small cells or are themselves shed, leaving behind a portion of their wall. These small cells and hairs are present in many members of the Liagoraceae (e.g., see Huisman and Kraft 1994: fig. 30, where remnant walls are visible on outer cells of Ganonema belminthaxis Huisman \& Kraft; and Huisman and Schils 2002: fig. 19, where the cells can be seen on Trichogloea requienii (Montagne) Kützing). Given the similarities between the cells and the hairs, it is possible that they are performing the same function. If so, it is unlikely that they are reproductive cells, which never take the form of hairs. What then might their function be? We cannot speculate, but an ultrastructural examination or chemical analysis of these cells would certainly be of interest.

Gametophytes of Gloiotrichus fractalis in Australia are found during the austral spring and summer, presumably overwintering as the (as yet unknown) filamentous tetrasporophyte. The Hawaiian plant was likewise collected during the boreal spring. The growing periods of the two collections are, therefore, not synchronous. Given this, plus the large geographical separation of the $\mathrm{Ha}$ waiian and Australian collection localities, it is almost certain that they are reproductively isolated. Molecular and culture studies would be of interest in ascertaining whether this isolation has been long-standing and has resulted in reproductive incompatibility or genotypic variation not expressed morphologically, or conversely whether either population is a recent introduction.

\section{ACKNOWLEDGMENTS}

We thank Marc Hughes, the collector of the specimen, and Karla McDermid (University of Hawai' $i$ at Hilo) for bringing it to our attention. Gerry Kraft (University of Melbourne) reviewed the manuscript and made numerous helpful suggestions.

\section{Literature Cited}

Abbott, I. A. 1999. Marine red algae of the Hawaiian Islands. Bishop Museum Press, Honolulu.

Holmgren, P. K., N. H. Holmgren, and L. C. Barnett. 1990. Index herbariorum. Part I: The herbaria of the world. 8th ed. New York Botanical Garden, New York [Regnum Vegetabile, Vol. 120].

Huisman, J. M. 1996. The red algal genus Coelartbrum Børgesen (Rhodymeniaceae, Rhodymeniales) in Australian seas, including the description of Chamaebotrys gen. nov. Phycologia 35:95-112.

. 1997. Marine benthic algae of the Houtman Abrolhos Islands, Western Aus- 
tralia. Pages 177-237 in F. E. Wells, ed. The marine flora and fauna of the Houtman Abrolhos Islands, Western Australia. Western Australian Museum, Perth. 2000. Marine plants of Australia. University of Western Australia Press, Nedlands.

Huisman, J. M., and G. T. Kraft. 1994.
Studies of the Liagoraceae (Rhodophyta) of Western Australia: Gloiotrichus fractalis gen. et sp. nov. and Ganonema belminthaxis sp. nov. Eur. J. Phycol. 29:73-85.

Huisman, J. M., and T. Schils. 2002. A reassessment of the genus Izziella Doty (Liagoraceae, Rhodophyta). Cryptogam. Algol. 23:237-249. 